\title{
0 pulo do gato da pequena indústria precária
}

\author{
Eduardo G. Noronha e Lenita Turchi
}

Introdução

Este artigo apresenta os resultados de pesquisas sobre Arranjos Produtivos Locais, que vêm sendo desenvolvidas no interior do país ${ }^{1}$. Arranjos Produtivos Locais (APLs) serão aqui tratados como um arranjo institucional inserido num ambienteinstitucional, tal como definimosa seguir. 0 foco da análise é no processo de transição da ilegalidade e/ou informalidade para a formalidadevivenciado por arranjos produtivosintensivos em mão-de-obra e inseridos em mercados precários nas regiões N ordeste e Centro-O este. $M$ ais especificamente, 0 artigo éorientado para responder as seguintes indagações: 0 que explica as origens e o sucesso de aglomerados produtivos industriais, no caso confecções, quesevêm desenvolvendo em regiões do interior do país com passado recente de economia baseada em atividades agrícolas? Q ue dimensões são importantes para explicar quando e como algunsAPLsforam capazes detransitar deuma situação caracterizada por produção ilegal ou informal, baixosníveis dequal idadeeprodutividade, baixos salários e condiç̧̃̃es de trabalho precárias para outro patamar mais alto em termos dequalidade, produtividade, salários e melhorescondições detrabaIho? Q ual tem sido o papel das instituições no processo de transição desses APLs de uma situação de crescimento desordenado de produção eemprego para a consolidação de atividades produtivas auto-sustentáveis capazes de gerar desenvolvimento local?

1. Este estudo faz uma reflexão sobre resultados do levantamento sobre APLs de confecções em Goiás e Pernambuco, e insere-se numa pesquisa mais ampla, financiada pela Redeipea, sobreaconstrução da cooperação em APLs. 
Argumentamosqueo processo de desenvolvimento dearranjos produtivos é múltiplo e complexo e vai além do proposto pelas principais abordagens teóricas que tratam do tema em termos de "vantagens competitivas", "existência de empresas líderes" ou "formação de redes de cooperação". $\mathrm{Na}$ agenda atual dos economistas, o debate sobre APL deriva do entendimento de que pequenas empresas aglomeradas num espaço podem ser competitivas e ter um papel importante no desenvolvimento nacional. A razão que explicaria o sucesso de um APL seria a existência de diversas formas de cooperação entre as empresas ou de uma mistura adequada entre competição e cooperação. Assim, o debate econômico voltou-se fortemente para as questões da cooperação e das relações entre firmas, e os fatores que permitem ou incentivam a cooperação entre empresas concorrentes. A cooperação (ou confiançatomada como pré-condição da cooperação) seria a principal razão do sucesso de APLs na visão de determinados autores. Esses temas passaram a ser centrais tanto na agen da daqueles que entendem a confiança ea coope ração como derivadas de ambientes com histórias de acúmulo de capital social, seguindo da tradição de Putnam (1993), como daqueles que entendem a cooperação como derivada de ações racionais na busca de maximização de interesses, e, portanto, passíveis de serem construídas a despeito de ambientes com histórias de conflitos (cf. Locke, 2004).

Em que pese a importância da análise centrada nas relações de confiança entre empresas, edessas com outras organizações internas de um APL, neste artigo mostramos a relevância deanálises macroinstitucionais, ou, mais precisamente, aquilo que definimos como os "ambientes institucionais" nos quais os APLs estão inseridos. H á um conjunto de condicionantes ou processos (de desenvolvimento ou ruptura) macroinstitucionais que marcam a história dos arranjos produtivos, particularmente o "marco legal contratual". Argumentamos, em primeiro lugar, que os padrões de contratos formais ou informais ea passagem de um tipo de contrato para outro definem o sucesso ou o fracasso de um APL. Em segundo lugar, consideramos que, particularmenteem APLs demão-de-obraintensiva, o significado do sucesso da política industrial inclui a criação de empregos de qualidade. N esses casos, política industrial epolítica de emprego não são dissociáveis. Por fim, sustentamos queo debate sobreAPL deveincluir a análise de certas especificidades da produção e do mercado em pequenos municípios.

Esses argumentos são ilustrados com os resultados de estudos real izados em dois arranjos produtivos de confecções, predominantemente de jeans, localizados no interior de Goiás e Pernambuco. Tanto o APL de Jaraguá 
(G O ) como o de Toritama (PE) são conhecidos pela geração de emprego e pelo crescimento econômico na última década, em áreas pouco dinâmicase sem passado industrial. O sAPLs investigados apresentam processos produtivos semelhantes, mas suas trajetórias em termos da transição vivenciada, assim como seus impactosno desenvolvimento local, são diferenciados. Enquanto o APL de Jaraguá transitou de uma situação caracterizada como ilegal (era conhecido por copiar marcas famosas) para a formalização das empresas e a criação de marcas próprias, o de Toritama evoluiu no sentido de um maior controleda poluição causada pelas lavanderias dejeans, masainda permanece com alta informal idade nos contratos enas relações de trabal ho.

A pesquisa revelou que esse processo de mudança resultou de momentos de crise ou rupturas, e não de uma evolução em que os atores teriam sentido necessidade de cooperar para a solução de problemas de interesse coletivo. Essa cooperação foi posterior ou, mais especificamente, só foi possível pela atuação de instituições que deram origem à crise e estiveram presentes no enfrentamento da mesma. No caso de Jaraguá, a instituição determinante da mudança foi a própria estrutura legal necessária para a inserção no mercado formal; já em Toritama, a promotoria pública e a agência governamental de meio ambiente levaram à necessidade de buscar soluções menos poluentes entre os empresários locais.

Este artigo é constituído de oito itens. N o primeiro, são apresentadas as questões que orientaram a pesquisa e os principais argumentos desenvolvidos. No segundo, sintetizamos o debate sobre elementos e condições que dificultam ou contribuem para o desenvolvimento de pequenas firmas em arranjos produtivos. No item seguinte, situamos os arranjos na agenda de políticas públicas, particularmente a política industrial do país. 0 quatro trata da metodologia e de estratégias da pesquisa de campo realizada em G oiás e Pernambuco. No quinto apresentamos as principais características econômicas e sociais e os processos produtivos dos arranjos. N os últimos itens, analisamos os resultados da pesquisa, particularmente o papel das instituições e dos atores envolvidos no processo de mudança.

APL como um tipo específico de arranjo institucional

Arranjos produtivos locais podem ser tomados como tradução simplificada de cluster, inclusive na ambigüidade que o termo em inglês envolve. Rigorosamente, o essencial da definição está (1) na especialidade da produção e (2) na delimitação espacial. Baseada nesses critérios "minimalistas", 
2.ReseSist, Rede de Pesquisa em Sistemas e Arranjos Produtivos el novativos Locais ( $w$ ww.redesist.ie.ufrj.br). qualquer concentração de um tipo de produção, seja numa região, município, bairro ou mesmo rua, pode ser denominada APL.

0 grupo responsável ${ }^{2}$ pela difusão do termo "sistemas produtivos locais", que deu origem ao atual APLs, trabalha com uma definição mais ampla do conceito, entendendo-o como concentração de agentes "econômicos, políticos e sociais, com foco em um conjunto específico de atividades econômicas e que apresentam vínculos mesmo que incipientes" (C assiolato e Lastres, 2003, p. 27). Essa formulação implica a introdução de dois novos elementos: (1) a idéia de interação entre as empresas e (2) a presença ativa de associações privadas ou sindicais eórgãos governamentais.

O utros autores, como W ilson Suzigan, João Furtado e Renato Garcia, têm avançado no sentido de dar uma definição mais precisa ao termo ao desenvolver critérios metodológicos que permitam caracterizar estatisticamente os diversos sistemas produtivos industriais com base numa série de indicadores de concentração de atividades econômicas de um mesmo setor ou cadeia com interações entre os diferentes atores do aglomerado. Em estudos realizados para os estados de São Paulo e Paraná, os autores sugerem a classificação dos sistemas identificados em quatro categorias definidas para abarcar tanto aglomerados incipientes com potencialidade de se transformar em arranjos produtivos, como núcleos maduros e avançados (cf. Suzigan, Furtado et al., 2003).

A definição "minimalista" deAPL mencionadaanteriormente(produção especializada, delimitada numa região) tem vantagens operacionais importantes. Ela explicita suas diferenças de abordagens como a de "cadeias produtivas", na qual édada ênfaseà relação vertical do sistema produtivo, independentemente de sua delimitação espacial, e também, portanto, à forma hierarquizada como os mercados se estruturam em el os nacionais einternacionais (cf. Gereffi eK orzeniewicz, 1990). C ontrapõe-se também à definição mainstream decluster, cuja ênfasenos principais estudosnão éa presença de especialização, mas justamente a concentração de boa parte da cadeia produtiva numa determinada região - a produção calçadista no Vale dos Sinos é o exemplo clássico.

APLs contrapõem-se às cadeias produtivas por sua vocação local e ao cluster por sua especialização. Contudo, essas três abordagens têm em comum o intuito de identificar os vínculos que explicitam as dinâmicas dos sistemas produtivos, deixando de lado a vel ha classificação das empresas por setor. Entendemos quea classificação setorial élimitada, dado quea abordagem centrada apenas nassimilaridades de produtores concorrenteséincapaz 
de verificar cooperações verticais ou horizontais entre empresas e entre essas e outras organizações que lhes dão apoio ou constrangem suas ações.

Por relações verticais de mercado entendemos aquelas que sedimentam relações típicas de cadeias produtivas, nas quais as empresas estão relacionadasumasàs outras de forma mais intensa do que por meras relações decompra e venda - por exemplo, cooperação tecnológica ou de treinamento. Podemos chamar de cooperação (ou conflito) vertical tanto aquelas relações entre segmentos de uma cadeia produtiva como aquel as entre capital e trabalho. Conseqüentemente, entendemos organizações verticais como as que sedimentam relações entre vendedores e compradores em busca de um benefício comum - ou "bem público", nos termos deO Ison ([1955] 1999) diantedeoutros competidores, os quais podem, por suavez, estar associados a outras organizações verticais. A dificuldadede obter tal tipo de cooperação e de construir organizações que lhe dêem continuidade é superar os conflitos de interesse, particularmente preços.

As relações horizontais de mercado são entendidas como aquelas estabe lecidas entre empresas similares, competidoras no mercado (por exemplo, empresas de um setor específico da cadeia, como as empresas de cal çados). O rganizações horizontais são criadas na busca ou na manutenção de bens públicos - por exemplo, redução de impostos, acordos de preços ou realização de feiras promocionais no exterior. Tais associações tipicamente direcionam suas demandas aos governos, aos seus fornecedores, aos seus compradores ou, ainda, agem no sentido de enfrentar coletivamente competidores externos. A dificuldade de estabelecer cooperação horizontal está em superar os conflitos da competição no mercado. Por fim, por organizações externas de mercado entendemos todas aquelas que visam à promoção das empresas e dos mercados, tais como os ministérios e outros órgãos governamentais ou paragovernamentais, como 0 Sistema $\mathrm{S}^{3}$.

Consideramos ainda que a compreensão da evolução de arranjos produtivos exige o estudo daquilo que H ollingsworth (2003) denomina "arranjo institucional" ao se referir aos cinco componentes da análise institucional: mercados, estados, redes, associações e comunidades são exemplos de arranjosinstitucionais; isto é, arranjos que, além de serem por si só institucionalizados, são compostos de múltiplas instituições e organizações 4 .

N este artigo, chamamos de "ambiente institucional" os dois componentes, digamos, mais amplos da análise institucional, tal como proposto por $\mathrm{H}$ ollingsworth, isto é, as "instituições" (normas, valores etc.) e os "arranjos institucionais" (mercados, comunidades etc.).
*A data entre colchetes refere-se à edição original da obra eé indicada na primeira vez em que a obra écitada. Nasdemais, indica-sesomente a edição utilizada pelo autor (N .E.).

3. U ma versão modificada da definição pode ser encontrada em N oronhaeTurchi (2002).

4. Além dos arranjos institucionais, $\mathrm{H}$ ollingsworth define outros quatro componentes da análise institucional: 1. instituições (normas, regras, convenções, hábitos e valores); 2 . organizações (empresas, associações, partidos, escolas etc.); 3. setores institucionais (sistema financeiro, sistema de educação, sistema de pesquisa; sistema social de produção); 4. resultados e desempenhos (estatutos, decisões administrativas, performance setorial e societária). 
Ao tratarmos APLs como arranjos institucionais, enfatizamos as regras do jogo, as normas, práticas e valores, e as organizações que dão existência formal e cognitiva aos APLs. Empiricamente isso significa um esforço em reconhecer todos os tipos de contatose conexões, formais ou informais, que permitem identificar um APL como uma unidade; isto é, um conjunto de empresas que possuam al guma identidade para além daquela de pertencerem a um mesmo ramo ou estarem localizadas numa região específica.

Consideramos que a identidade específica de um APL pode ter origem tanto interna às empresas do setor (os agentes das empresas participam de alguma ação comum), como externa e independente de suas vontades (as empresas conformam um mercado identificado como tal tanto por seus clientes e fornecedores como pela mão-de-obra, o mercado de trabalho).

O sAPLsconsolidadossão aquelescujasidentidades endógenase exógenas são reconhecidas pelos atores e, portanto, observáveis pel os pesqui sadores. A ausência de uma das identidades expressa al guma fragilidade do arranjo, e tende a explicitar a própria origem de um APL, isto é, APLs criados de forma coordenada e deliberada (alta identidadeinterna) eAPLscriados pelo mercado. Aos primeiros falta a consolidação do reconhecimento público (do mercado de compradores e da mão-de-obra) que lhe garanta a permanência caso os esforços de coordenação sejam afrouxados; aos segundos faltam mecanismos de coordenação que evitem competições destrutivas entre os membros do APL ou que potencializem suas vantagens competitivas em relação a outros mercados.

\section{APLs na agenda de políticas públicas}

A discussão sobre a definição e o papel deAPLs no âmbito das políticas industriais e sociais ganhou importância durante o primeiro governo Lula. A sinalização governamental de criação de políticas de apoio aos APLs ge rou esforços de diversos municípios, regiões e estados da Federação no sentido do reconhecimento de que seus aglomerados produtivos fossem classificados como APLs. N a interpretação de técnicos e políticos, a "marca APL" tornou-se necessária para o possível acesso a políticas públicas, o que ampliou sobremaneira o significado coloquial de "APL".

Ao incluir a promoção de Arranjos Produtivos Locais entre as diretrizes da Política Industrial de Inovação e Comércio Exterior (PITCE), o poder público e as organizações não governamentais assumiram os argumentos presentes na agenda acadêmica sobre a necessidade de promover 
um ambiente institucional que fortaleça pequenos empreendimentos em grupos. Essa orientação de política pública parece substituir a visão assistencialista, predominante em períodos anteriores, segundo a qual os pequenos empreendimentos devem ser subsidiados e/ ou isentados de cumprir obrigações fiscais e trabal histas, em prol de uma visão mais otimista das potencialidades de pequenos empreendimentos. N essa concepção, pequenos empreendimentos são capazes de produzir inovações e promover o crescimento econômico com geração de emprego e renda de forma autosustentável nas mais diversas regiões do país. Conseqüentemente, a proposta de promover pequenos empreendimentos em arranjos locais retomou 0 debate, até então relegado ao segundo plano, sobre a dimensão regional e local do desenvolvimento industrial.

Embora seja prematuro fazer previsões se de fato a promoção de pequenos empreendimentos via APLs será uma estratégia governamental de caráter mais permanente, constituiu-se um grupo de trabalho interministerial composto por representantes de 33 instituições e organizações públicas e privadas de âmbito federal, que recebeu a denominação de G rupo deTrabal ho Interministerial de Arranjos Produtivos Locais (GTPAPL). A novidade da proposta recém-lançada em relação ao que foi praticado no passado é o esforço de atuação integrada entre os diversos órgãos, aliado à percepção de que os APLs devem ter políticas específicas e coordenadas pelo governo federal.

No período de 2004 a 2006, o grupo interministerial atuou basicamente em duas vertentes. A primeira buscou reunir as diversas instituições, governamentais e não governamentais, em nível federal, que desenvolviam atividades em aglomerações consideradas arranjos produtivos, e identificar as ações realizadas por elas nesses APLs. A segunda foi promover a cooperação entre as instituições federais e as locais no apoio aos Planos de D esenvolvimento elaborados nos APLs selecionados.

E mbora existam indicadores de desempenho positivo das empresas nos APLsselecionados, essas experiências são recentes e o sucesso eas limitações dessa forma de atuação ainda estão por ser estudados. D a mesma forma, ainda está por ser feita uma análise mais sistemática do desempenho e do desenvolvimento do grupo interministerial. Embora seja prematuro real izar uma avaliação da experiência de cooperação institucional, cabe ressaltar alguns aspectos da forma de atuação do G T PAPL.

Em primeiro lugar, destaca-se o reconhecimento por partedo poder público da necessidade de integrar instituições na solução de problemas coleti- 
vos. 0 esforço realizado pelas instituições na mobilização dos agentes dos APLs e no acompanhamento dos planos de desenvolvimento resultantes contribuiu para um maior conhecimento dos recursos e atividades das diversas instituições envolvidas, o que em muitos casos permitiu que de fato houvesse uma atuação conjunta nos APLs. Entretanto, a integração na elaboração deplanos de desenvolvimento para osAPLsétemporária, eaausência de recursos próprios para gerir as atividades do GTPAPL faz com que a atuação dependa das prioridades e dos recursos de cada ministério ou agência. Assim, em vez de um plano conjunto, o grupo conseguiu no máximo coordenar as atividades de cada ministério para o APL em questão. Além disso, dado queo Arranjo Produtivo Local foi tomado por agentes estaduais como instrumento para promoção de desenvolvimento local, o GTPAPL sofre pressões políticas principalmente na seleção dos arranjos a serem trabalhados. M as, como mencionado anteriormente, essa é uma experiência recente que merece ser avaliada em estudos futuros.

Pesquisa

\section{0 trabalho de campo}

A pesquisa decampo nosArranjos Produtivos dejaraguá eToritamabuscou responder questões sobrea natureza dosarranjosintensivosem mão-deobra no interior do país, bem como sobre o processo de transição da informalidade para estruturas produtivas mais consolidadas e formalizadas. A pesquisa empírica tevecomo foco as relações institucionaiseostipos decontrato realizados nos arranjos, incluindo os seguintes aspectos: a) a presença deorganizações públicas ou agências de apoio às empresas; b) a natureza das relações estabelecidas entre essas organizações e os empresários; c) a avaliação dos empresários sobre o desempenho das organizações no apoio não só ao desenvolvimento da empresa mas também do arranjo como um todo; d) os tipos e a natureza dos contratos (em termos de estabilidade e níveis de satisfação) estabelecidos entre as diversas empresas fornecedoras e com as contratadas para real izar as diversas etapas do processo deprodução dejeans; e) o padrão de contratação do trabalho (formal/informal) e as principais questões ou foco de tensões e conflito entre empresários e trabal hadores.

Para tratar desses tópicos, a pesquisa de campo foi realizada em duas etapas num período de dezoito meses, fazendo uso das seguintes estratégias metodológicas: 
1. Entrevistas semi-estruturadas com líderes empresariais, representantes locais e estaduais de organizações públicas, representantes do ministério público, membros de agências governamentais e não governamentais com ações na região, representantes sindicais dos trabal hadores da confecção em Goiânia eJaraguá, em Goiás, eem Recife, Toritama, C aruaru eSanta Cruz, em Pernambuco.

2. Survey com empresários, sob a forma de questionário contendo questões fechadas sobre as formas de contratos e abertas para captar a avaliação dos mesmos sobre as organizações que atuam nos arranjos. 0 survey cobriu 54 empresas, sendo 32 em Jaraguá (vinte formais e doze informais) e 22 em Toritama (oito informais e 22 informais). A proporção de formais e informais foi definida na pesquisa com base em informações pre liminares e precárias a respeito da proporção de empresas informais na região.

3. Entrevistas abertas e informais com empresários de microempresas, lojistas, políticos locais e trabal hadores dos diversos segmentos da confecção. Considerando a dificuldade de tratar alguns dos temas centrais da pesquisa (produção ilegal, trabalho infantil, evasão fiscal), essas entrevistas não foram gravadas. $C$ abe ressaltar que elas foram decisivas no entendimento das estratégias da falsificação, assim como na identificação dos fatores que levaram à mudança ou ruptura com essa forma de atuação.

\section{APLs típicos: informalidade e processos produtivos}

O s arranjos de Jaraguá eToritama foram selecionados com base nas informações da Rais, que apontaram um crescimento do emprego formal nesses municípios no período de 1995 a 2000 da ordem de 142\% (Jaraguá) e 115\% (Toritama), quando o setor de confecções no país 5 vivia momentos de crise e estagnação. Essa opção foi reforçada por indicações de agentes de instituições que atuam na área, como Sebrae, Senai e técnicos das secretarias de planejamento dos estados de G oiás e Pernambuco, que viram nesses arranjos um processo de crescimento euma transição bem-sucedida ou uma ruptura com os antigos padrões produtivos baseados na ilegalidade ou na informalidade.

Além disso, Jaraguá e Toritama apresentavam um conjunto de características que aparentava constituir um "tipo ideal" de arranjo produtivo de acordo com nossa definição: municípios no interior do país com um nicho específico (jeans), em estágio inicial (com apenas cerca de vinte anos de
5.0 crescimento do número de empregados no setor de confecções no período entre 1995 e 2000 foi da ordem de $1,4 \%$, e do número de empresas, 8\% (Rais). 
história), com indicadores de sucesso especialmente nos últimos cinco a dez anos. Trata-se de um segmento de baixa tecnologia e mão-de-obra intensiva - ênfase escolhida para esse estudo de caso justamente por acrescentar mais um ator relevante no sucesso do APL (os trabalhadores e suas organizações) e um problema de política pública no que diz respeito ao desenvolvimento local e à geração de emprego.

O s arranjos investigados apresentam uma série de similaridades. Ambos fabricam jeans num sistema produtivo semelhante, ou seja, um processo segmentado no qual as diversas etapas do processo (design, corte, costura, lavagem, acabamento e distribuição) são realizadas por grupos diferentes e com baseno baixo custo do trabalho. Além dessa similaridade, os dois arranjos estão localizados em cidades de pequeno porte no interior do país, com passado econômico predominantemente rural e pouca ou nenhuma tradição industrial antes da consolidação da produção de jeans. Foi no final da década de 1990 que as cidades deToritama ejaraguá passaram a ser conhecidas como cidades dos jeans. Inicialmente, a fama de Toritama era produzir jeans dequalidadeduvidosa mas debaixo custo, ea de araguá era reproduzir com exatidão cópias, também de baixo custo, de marcas famosas, para 0 mercado local eregional. N osúltimosanos, esses doisarranjosiniciaram um processo de transformação não apenas no sentido da formalização das empresas e da criação de marcas próprias, mas também com a preocupação de incorporar valor pela melhoria de qual idade dos produtos e a ampliação de mercados. Entender a natureza do processo, as instituições e os atores que influíram nessa transição éo desafio a que se propõe esta pesquisa.

Contrastes: Jaraguá, mercado ilegal e IDH crescente; Toritama, poluidora e renda crescente

6. Censo demográfico de 2000.

As empresas que constituem o APL de Jaraguá estão concentradas no município de Jaraguá ( $G 0$ ), com uma área de $1.895,6 \mathrm{~km}^{2}$ e população aproximada de 34 mil habitantes ${ }^{6}$. Até meados de 1980, quando do desenvolvimento de uma indústria de confecção para atender o mercado local, 0 município tinha uma economia de base rural em que predominava a criação de gado ea produção de abacaxi. A expansão do comércio de confecção foi facilitada pela proximidade de Jaraguá à rodovia Belém-Braślia. N a dé cada de 1990, a produção das confecções expandiu-se sistematicamentetanto em Jaraguá como nos municípios vizinhos de São Francisco de Goiás, I taguaru, U ruana e Goianésia. 
Segundo o levantamento realizado pelo Sebrae-Go em 2005, foram identificadas, nos municípios que constituem o arranjo, 813 firmas envolvidas na confecção, lavagem e distribuição de jeans. D esse número, 68\% são informais. Embora a informalidade ainda seja grande, a consolidação dos APLs de Jaraguá e Toritama pode ser observada pelo crescimento do número de empregados formais nas atividades de confecções ( $Q$ uadro 1 ).

QUADRO 1

Evolução do N úmero de Empregados Formais em Empresas de Confecções

\begin{tabular}{l|c|c|c|c|c|c|c|c|c|c|c}
\hline M unicípIOS & 1995 & 1996 & 1997 & 1998 & 1999 & 2000 & 2001 & 2002 & 2003 & 2004 & 2005 \\
\hline Toritama & 140 & 106 & 98 & 299 & 295 & 301 & 462 & 608 & 837 & 1266 & 1281 \\
Caruaru & 569 & 637 & 1384 & 1995 & 2131 & 1965 & 2102 & 2415 & 2872 & 3469 & 4138 \\
S. Cruz do & 51 & 71 & 70 & 469 & 764 & 741 & 870 & 1058 & 984 & 1294 & 1533 \\
Capibaribe & & & & & & & & & & & 1617 \\
Jaraguá & 544 & 556 & 850 & 927 & 914 & 1318 & 1559 & 1645 & 1685 & 139
\end{tabular}

Fonte: Rais.

GRÁFICO 1

Evolução do N úmero de Empregados em Empresas com CN A 18

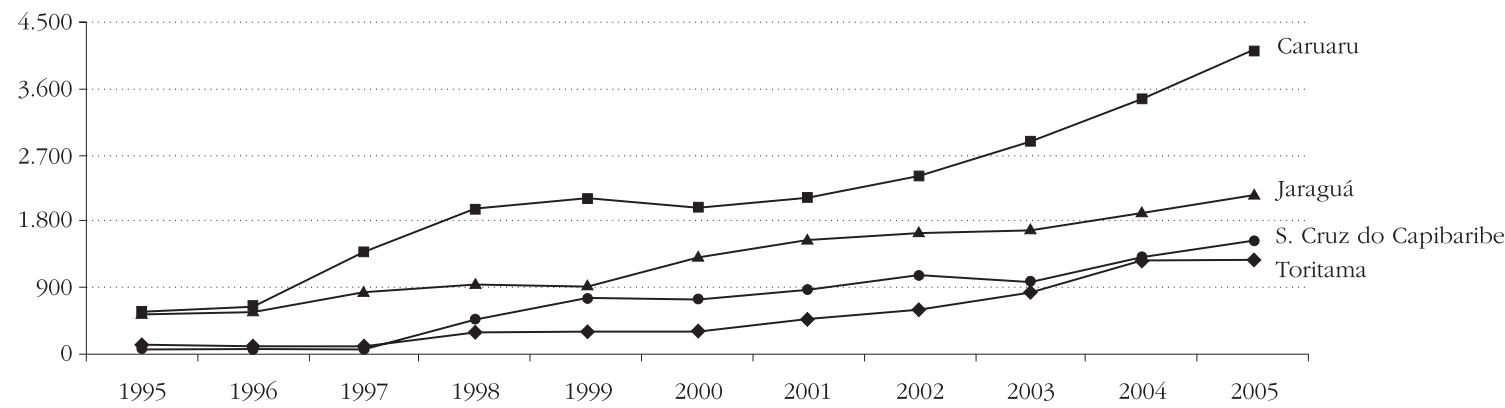

Evolução:

$\begin{array}{llll}\text { Caruaru: } & \text { 05/95: } 3.569(627 \%) & \text { 05/00: } 2.173(111 \%) & 00 / 95: 1.396(245 \%) \\ \text { Jaraguá: } & \text { 05/95: } 1.595(293 \%) & 05 / 00: 821(62 \%) & 00 / 95: 774(142 \%) \\ \text { S. Cruz do Capibaribe: } & \text { 05/95: } 1.482(2.906 \%) & 05 / 00: 792(107 \%) & 00 / 95: 690(1.353 \%) \\ \text { Toritama: } & 05 / 95: 1.141(815 \%) & 05 / 00: 980(326 \%) & 00 / 95: 161(115 \%)\end{array}$

As taxas de crescimento do emprego no setor, nosmunicípios dos arranjos estudados, apesar de diferentes e captando apenas os empregos formais, revelam uma evolução positiva no período entre 1995 e 2005. A despeito das imprecisões dos dados da Rais, com tal nível de desagregação, os dados 
indicam um grau de sucesso do APL, particularmente para anos deaumento do desemprego e do emprego informal.

D ados da Rais mostram também um crescimento do número de firmas nesse mesmo período em todos os municípios dos arranjos. Em Jaraguá, a taxa de crescimento foi da ordem de $262 \%$ e em Toritama, de $1.386 \%$. Tanto em Jaraguá como em Toritama predominam micro e pequenas empresas com menos de dez pessoas ocupadas e faturamento anual de até $R \$$ $10.000,00$ (dez mil reais).

Ao contrário de Jaraguá, cuja produção era pouco conhecida nos mercados regionais, dado seu caráter ilegal, o arranjo deToritama faz parte de um conjunto de municípios localizados na região semi-árida de Pernambuco, onde se destacam Santa C ruz do C apibaribee C aruaru, produtores de confecções de mal has e jeans popularizadas em feiras regionais como a Sulanca, abreviação da expressão "helanca do sul". Trata-se de um tipo de malha popular na década de 1970 cujos retal hos eram trazidos das fábricas paulistas para a confecção de peças de vestuário infantil e colchas. No vocabulário popular, servia para designar a produção de baixo custo equalidadeduvidosa que abastecia feiras locais regionais como a de $\mathrm{C}$ aruaru.

$\mathrm{N}$ as décadas seguintes, Santa C ruz do C apibaribe especializou-sena confecção de malhas eToritama na produção de Pólo de Confecções do Agreste. Segundo estimativas do Sindivest (Sindicato do Vestuário de Pernambuco), Toritama eos municípios vizinhos produzem uma média de 24 milhões de pares de jeans anualmente, o que corresponde a aproximadamente $12 \%$ da produção de jeans no país.

Assim como Jaraguá, Toritama tem um passado rural recente com predomínio da agricultura familiar, prejudicada pelos freqüentes períodos de seca dessa região semi-árida do N ordeste. Em Toritama, município de 34,8 km² com 22 mil habitantes, existiam em 2003 aproximadamente 2.190 empresas de confecção de jeans e sessenta lavanderias de prestação de servi-

7. Relatório da Fadel Universidade Federal de Pernambuco e Sebrae, 2003. ços de preparação dos jeans ${ }^{7}$. A pesar do dinamismo econômico, Toritama tem sérios problemas de ausência de serviços de infra-estrutura básica, como abastecimento de água e sistema de tratamento de esgoto, escolas e serviços de saúde. Essa situação pode ser constatada quando comparamos a evolução da renda per capita da população com os Indicadores deD esenvolvimento H umano do município ( $Q$ uadro 2).

O bserva-se no Q uadro 2 que o município de Toritama apresentou, nos dois períodos, renda per capita superior à média do estado de Pernambuco. Essa relação não se reproduz quando observamos indicadores 
sociais mensurados pelo Índice de D esenvolvimento $\mathrm{H}$ umano ${ }^{8}$. N esse caso, Toritama apresentou índices menores que a média do estado de Pernambuco e dos municípios vizinhos. $\mathrm{N}$ o tocante ao ID H médio e ao ID H de educação, o município de Jaraguá apresentou maior crescimento que o deToritama.
8.0 IDH é calculado pela média simples de três subíndices referentes às dimensões de Longevidade (ID H M L), Educação (ID H M E) eRenda(IDHM -R).

QUADRO 2

Renda per capita e Índice de D esenvolvimento H umano - ID H

\begin{tabular}{|c|c|c|c|c|c|c|c|c|c|}
\hline \multirow[t]{2}{*}{ MUNICÍPIOS } & \multicolumn{2}{|c|}{$\begin{array}{c}\text { RENDA PER CAPITA } \\
-2000 R \$\end{array}$} & \multirow{2}{*}{\begin{tabular}{|l} 
EvoluçÃo \\
$1991-2000$ \\
\end{tabular}} & \multicolumn{2}{|c|}{ IDHM } & \multirow{2}{*}{$\begin{array}{l}\text { EVOLUÇÃo } \\
\text { 1991-2000 }\end{array}$} & \multicolumn{2}{|c|}{$\begin{array}{c}\text { IDHM } \\
\text { EdUCAÇÃOO }\end{array}$} & \multirow{2}{*}{\begin{tabular}{|c|} 
EvoLUçÃo \\
$1991-2000$ \\
\end{tabular}} \\
\hline & 1991 & 2000 & & 1991 & 2000 & & 1991 & 2000 & \\
\hline BRASIL & 230,30 & 297,23 & 29,10 & 0,70 & 0,77 & 0,07 & 0,74 & 0,85 & 0,11 \\
\hline GoIÁs & 211,90 & 285,96 & 35,00 & 0,70 & 0,78 & 0,08 & 0,76 & 0,86 & 0,10 \\
\hline Jaraguá & 125,20 & 194,48 & 55,30 & 0,64 & 0,73 & 0,09 & 0,69 & 0,80 & 0,11 \\
\hline Pernambuco & 141,37 & 183,76 & 30,0 & 0,62 & 0,71 & 0,09 & 0,64 & 0,77 & 0,03 \\
\hline Toritama & 172,42 & 195,27 & 13,30 & 0,64 & 0,67 & 0,03 & 0,64 & 0,67 & 0,03 \\
\hline Caruaru & 161,62 & 209,76 & 29,80 & 0,65 & 0,71 & 0,06 & 0,65 & 0,71 & 0,06 \\
\hline $\begin{array}{l}\text { S. Cruz do } \\
\text { Capibaribe }\end{array}$ & 168,57 & 207,86 & 23,30 & 0,64 & 0,70 & 0,06 & 0,63 & 0,69 & 0,06 \\
\hline
\end{tabular}

Fonte: I peadata.

D e fato, o crescimento econômico da região do APL de Toritama no período entre 1991 e 2000 não foi acompanhado por melhorias na qualidade de vida da população. A cidade de Toritama, que concentra 98\% da população do município, sofre pela ausência de serviços básicos de saneamento, saúde eeducação. A té 2005, o município, além da escassez deágua, vivia o problema da poluição gerada pelas lavanderias, que despejavam os resíduos da lavagem do jeans no único rio da cidade. $\mathrm{N}$ a busca de solução para os problemas de falta de água e de poluição, os produtores de jeans de Toritama e os atores governamentais iniciaram um padrão de conduta que tem promovido o desenvolvimento do arranjo. As instituições e os processos responsáveis pelas mudanças que ocorreram tanto em Toritama como em Jaraguá serão discutidos a seguir.

Confiança, famílias e as lógicas da pequena produção em municípios do interior Confiança, autoridade e família 
9. Há ampla literatura sobre os limites do mainstream neoclássico. Ver, entreoutros, Swedberg (1994); M arsden (1986); Solow (1990); Granovetter eSwedberg (1992); Di Maggio e Powell (1983).
O s debates sobre "confiança" e "custos de transação" intensificaram-seà medida que cresceu a percep ção de que o mercado impessoal éapenas uma abstração que ajuda a entender as lógicas básicas de seu mecanismoํ. A despeito disso, a própria sociologia econômica tem dado pouca atenção a um tipo específico de confiança, isto é, aquelas derivadas de relações familiares. As noções de confiança e de cooperação, tal como definidas pela literatura sobre empresas em mercados complexos, não tratam desse tipo de relação justamente porque as ligações familiares são margi nais na definição de me canismos de mercados.

Se tomarmos os dois princípios utilizados por Benedicte Reynaud para definir confiança ("delegação" e "antecipação de comportamento"), percebemosquenas relaçõesfamiliares a noção de delegação épouco adequada. A autora argumenta que, entre os analistas, há um entendimento comum do tema quepodeser sintetizado da seguinteforma: "uma anteci pação do comportamento do outro em função da qual eu baseio minha própria ação" (2004, p. 79) . Ainda de acordo com Reynaud, contudo, outras relações, sobretudo a de "autoridade" (noção quase oposta à de confiança), permitem que um indivíduo paute sua ação com base no comportamento antecipado do outro. D aí a necessidade da noção de del egação como prévia à de antecipação. Assim, na definição de Reynaud, "confiança éuma relação de delegação que sefunda na antecipação do comportamento do del egatório" (I dem, ibidem).

Porém, nas relações econômicas familiares, o princípio de autoridade está mais presentequeo de delegação, pois o produto do trabal ho dos membros, principalmente em se tratando de família nuclear, é controlado por aquele(a) considerado(a) chefedo domicílio. N osempreendimentos debase familiar, a questão da cooperação deriva deum misto (1) derelações deautoridade, (2) de mecanismos de controle explícitos típicos de relações familiares ou tradicionalistas, (3) do reconhecimento de interesses mútuose (4) da sedimentação deconfiança, no sentido dado por Reynaud. Tratar a cooperação como requisito de desenvolvimento de APLs, como resultante apenas demaximização de interesses individuais ou derivada da noção moderna de delegação (como contraposta a autoridade), é apenas parte da explicação: justamente aquela que trata dos componentes não familiares da confiança ou da autoridade legítima.

A análise de arranjos produtivos em pequenas cidades deve retomar os temas das relações familiares e do patriarcalismo, presentes em várias regiões brasileiras. A literatura internacional os trata de forma marginal, su- 
pondo que as relações tradicionais e patriarcais são resquícios de pequenas comunidades e irrelevantes para o debate do desenvolvimento e da industrialização.

\section{A longa crise do Brasil arcaico - família, informalidade e produção precária}

À semelhança da literatura internacional sobre arranjos produtivos, a nacional não tem dado ênfase ao estudo das empresasfamiliares esuas transições para empreendimentos profissionalizados ${ }^{10}$, como se a crise do Brasil arcaico tivesse se encerrado como descrito há quarenta anos por Juarez Brandão Lopes (1967) em seu livro. 0 nascimento e o desenvolvimento de arranjos produtivos são tratados como se as transições de economias rurais ou locais para a constituição de arranjos produtivos locais não fossem proble máticas ou constituíssem casos excepcionais e, portanto, irrelevantes.

$\mathrm{N}$ a verdade, não sabemos ao certo quantos clusters ou arranjos produtivos passam ou passaram por processos semelhantes aos que encontramos em Jaraguá e Toritama. D ado o elevado número de municípios com menos de 50 mil habitantes no Brasil e o número de pequenas empresas, pode-se supor que esses municípios exemplifiquem a história de muitos outros.

A típica empresa dos arranjos produtivos aqui estudados nasce como uma confecção pequena e informal incentivada por um parente ou patrão (em geral compadre ou amigo), financiada com a venda de um automóvel ou pequena propriedade, ou empréstimos de parentes ou amigos. 0 investimento inicial para a abertura varia consideravelmente, dependendo do tipo de empresa - 34 das 54 empresas entrevistadas nasceram com investimentos iniciais de até 3 mil reais; somente duas empresas começaram com capital superior a 80 mil reais.

A produção de jeans envolve os processos de design, modelagem, corte, costura; de casear, travetar, chulear, catar linha, pregar botões, lavar, bordar ou aplicar enfeites, passar a ferro, embalar para transporte; e, por fim, de venda edistribuição. Esse processo produtivo podeser organizado de várias formas, sendo rarosos casosem que apenas uma empresa executa todas essas etapas. N os municípios investigados, a produção do jeans envolve normalmentecinco tipos deempresas (ou autônomos). 0 desi gn évendido por um especialista, normalmente residente em G oiânia, no caso de Jaraguá, e Caruaru, no caso de Toritama, que trabal ha para diversas confecções; modelagem, corte e costura são realizados pela "confecção dona de uma marca" e coordenadora de todo o processo. G rande parte delas usa os chamados "aca-
10.H á exceções no campo da antropologia econômica e da sociologia econômica demigrantes- ver, por exemplo, Grun (1992). M as não há diálogo entreas abordagenssociológicas e antropológicas sobre famílias (economia) e as análises sobre arranjos produtivos locais. 
11.Em Toritama, dezoito das 22 empresas praticam contratos de trabal ho informais, exclusiva ou majoritariamente. Em Jaraguá, as empresas nasquais predominam os contratos formais (16) superam as informais (11). bamentos pré-lavagem" (no caso de) araguá) ou "facções" (no caso deToritama). O s "acabamentos" possuem máquinas para casear, chulear e fixar botões de pressão eoutras atividades que exigem equipamentos especializados e, portanto, investimentos superiores às próprias confecções que os contratam. Após esses trabal hos, a roupa vai para a lavanderia, ondeo jeans recebe tratamentos que alteram a coloração e a textura do tecido (stonagem). D a lavagem, o jeans segue para os "acabamentos pós-lavagem" ("catar linhas" e passar a ferro).

Em Toritama, a fragmentação do processo produtivo é ainda maior. As etapas que em Jaraguá são denominadas de "prélavagem e "pós-lavagem", em Toritama são fragmentadas em inúmeros tipos de facções ou "aprontamentos", como são chamadas, em geral localizadas na própria casa dafamília e que freqüentemente avançam pelas cal çadas. 0 mesmo ocorre com as lavanderias, que se espalham em fundos de quintais na área urbana, ao longo do rio $C$ apibaribe.

A análise agregada dos dados coletados pelas entrevistas em Jaraguá indica a fortíssima predominância de confecções formais (doze das treze confecções), queno entanto praticam os mais diversos tipos de contratos informais: o proprietário ou os sócios informais são responsáveis pelo design, modelagem, corte e distribuição; os trabal hos de costura e de pré-lavagem são majoritariamente feitos por empregados "CLT istas", mas as confecções contratam também trabal hadores informais ${ }^{11}$, repetindo a prática comum no Brasil de formalizar os empregados mais antigos como uma espécie de prêmio. U sam também, em menor medida, o trabalho de empresas informais tercei rizadas. Só uma das empresas possui os serviços de lavanderia dentro da própria confecção. Todas as outras contratam informalmente lavanderias externas. N ote-se que esses contratos são informais apesar de tanto as confecções (doze das treze entrevistadas) como as lavanderias (as cinco utilizadas pelas confecções) serem formais. N os trabalhos de pós-lavagem, somente três confecções utilizam seus empregad os C LT istas. A grande maioria terceiriza esse serviço para autônomos informais. 0 trabal ho de bordados, quando há, é sempre terceirizado informalmente. O s sócios informais e os proprietários são encarregados da distribuição, aliada à utilização de autônomos informais.

Toritama diferencia-se de Jaraguá pela predominância quase absoluta de contratos informais. D estaca-se também a pequena atividade manufatureira dentro da confecção, com a maior parte dessas atividades sendo realizadas por meio de terceirizações informais (autônomos ou empresas). N esse 
município, os limites entre "confecção", "facção" ou "aprontamento" são tênues. Ter uma confecção pode significar ter o controle sobre apenas um ou dois dos quatro principais processos (design; moldagem e corte; costura; e distribuição), os quais, em Jaraguá, são centralizados por quase todas as confecções. Em Toritama, a feira éo fator de identificação de uma "confecção": ter uma barraca na feira em geral significa ter uma confecção. A venda na feira éa maneira como se informam as tendências da "modinha"12. M uitos produtos são concebidos na feira, seja por meio de cópia das peças de maior sucesso, seja pelas sugestões ou demanda do público. As três feiras locais semanais (C aruaru, Santa C ruz do C apibaribe e Toritama) estruturam a produção em Toritama, ao passo que em Jaraguá é a cópia (antes falsificação ehojesimples "inspiração") bem feita de marcas consagradas no mercado, voltada para as classes médias, que permite a conquista de um amplo mercado comprador no C entro, $\mathrm{N}$ orte e $\mathrm{N}$ ordeste do país.

\section{Investimento familiar}

D uasrazões destacam-separa a criação dasempresasnessesAPLs: o fato de as cidades serem reconhecidas pela sua produção (Jaraguá eToritama são fa mosas como cidades dos jeans) e a facilidade de obten ção de material para a produção. M as somente uma das 54 empresas investigadas buscou e obteve apoio financeiro institucional para a sua criação. I sso se explica tanto pela ausênciadepolíticascomo, principalmente, pela redesocial deincentivosàcriação de empresas, em especial os acabamentos pós-lavagem e as facções, isto é, as empresas auxiliares (deterceirização de etapas da produção) debaixo investimento inicial - queem geral não ultrapassa os 2.500 reais. A expansão permanentedosmercados para osprodutos do município possibilitou queacriação denovasempresas fossebem vistaeincentivada pelos própriosprodutores concorrentes. A dinâmica positiva deaglomeração foi rapidamentepercebida edifundida por meio de relações familiares e de compadrio misturadas a relações de trabalho. Freqüentemente empregados-parentes foram incentivados por seus patrões a abrirem acabamentos ou mesmo confecções. Esses, também por intermédio de relações pessoais, saíam em busca denovosmercados, costumeramenteno $\mathrm{N}$ ortee $\mathrm{N}$ ordestedo país.

A ausência de instituições de apoio no surgimento dos arranjos, incluindo a prefeitura, mostra um tipo específico de expansão não induzida por qual quer nível de governo ou qual quer agência pública- organizações essas em geral relevantes para o entendimento da expansão de atividades produ-
12. "M odinha" éo termo utilizado para as peças fabricadas com rapidez (idealmente concebidas e produzidas de uma semana para a outra) com base nos figurinos utilizados nas novelas ou nos programas de TV de maior sucesso. 
tivas urbanas industriais em pequenas cidades. A falta detradição industrial dos municípios e a presença de produção pirata em Jaraguá e informal de baixa qualidade em Toritama podem explicar tais ausências.

APLs informais e o problema da representação dos interesses

Embora a variação no emprego formal seja uma dimensão importante no estudo dearranjos produtivos, ela éinsuficiente para caracterizar a dinâmica do emprego nos APLs, particularmente aqueles de mão-de-obra intensiva. Em primeiro lugar, há de se considerar que em APLs centrados em atividades de mão-de-obra intensiva, em que predominam micro e peque nos empresas, a informalidade é expressiva. U ma vez que as estatísticas oficiais disponíveis referem-se exclusivamente ao emprego formal, a dimensão dos APLs é sempre subestimada. 0 caso do APL de confecção no Agreste

13. Estudo de Caracte rização Econômica do Pólo de Confecções do Agreste Pernambucano, 2003. Fade/UFPE/ Sebrae.
Pernambucano ilustra essa situação. Segundo estimativas ${ }^{13}$, em 2003, das 7.945 empresas de confecção, apenas 945 (7,9\%) eram formais. D ados da Rais apontam em 2005 a existência 6.971 trabal hadores formais ocupados nas atividades de confecção nesses municípios. Entretanto, mantendo a proporcionalidade de informais encontrada nas empresas, é de esperar que esse contingente de trabalhadores formais represente apenas a ponta do i ceberg das pessoas ocupadas nas atividades do arranjo.

As relações estabel ecidas entre as institui ções eas organizações locais que representam os interesses dos diversos atores envolvidos nas atividades produtivas são dimensões igualmente relevantes para o desenvolvimento do APL. N o caso de arranjos intensivos de mão-de-obra, as organizações representativas de empregadorese de empregados no setor deatividade econômica predominante no arranjo assumem maior relevância, pois atuam no sentido de definir padrões de regulação do trabalho no âmbito do aparato jurídico e das práticas e condições de trabalho, mediando conflitos entre os dois segmentosmaisimportantes do arranjo. Por ser um típico APL de mãode-obra intensiva bem-sucedido na geração de empregos, esperávamos encontrar em Jaraguá eem Toritama organizações atuantes tanto na mediação de conflitos como na qual ificação de trabal hadores da indústria de confecção. Entretanto, essas instituições têm tido pouca expressão na região dos arranjosinvestigados.

Em Toritama, o delegado sindical dos empregados do setor de confecções, designado para a região, havia recém-chegado de Recife e não tinha bases nem apoio no município. N aquele momento, sua preocupação era 
orientar os trabal hadores quanto aos seus direitos e ampliar as bases locais sem criar conflitos ou aumentar a desconfiança com que foi recebido por ambas as partes.

As relações e as condições de trabal ho, principal mente nas empresas informais e pequenas lavanderias predominantes no arranjo, caracterizam-se pela precariedadeeinsalubridadedas construçõesondeestão as confecçõese facções informais, além da ausência de requisitos mínimos de segurança para atuar nos fornos das lavanderias. Em Toritama, o desrespeito à legislação trabalhista era visto como um problema menor diante da escassez de água e da poluição causada pel as lavanderias. N esse município, a promotoria pública, em articulação com agentes governamentais ligados ao meio ambiente, atuou como catalisadora das mudanças na forma de tratamento dos efluentes das lavanderias. Esseprocesso será discutido no próximo item.

N o caso de Jaraguá, os trabal hadores são representados por uma del egada sindical ${ }^{14}$, cujas práticas efetivas ultrapassam em muito aquelas previstas pelo seu cargo. Alguns dos entrevistados referiram-se a ela como "fiscal do trabalho", outros como "alguém da Justiça", outros ainda destacaram seu bom-senso como sindicalista e alguns empresários a criticaram por querer ensiná-los a lidar com os empregados. Em geral, é vista por ambos (trabaIhadores e empregadores) como alguém que "ajuda muito", pois, além de conhecer a contabilidade das empresas e os dispositivos da CLT, atua mediando conflitos e "aconselhando empresários". Acordos trabal histas informais são realizados com freqüência na sede do sindicato, muitos deles sem nenhum registro ou assinatura das partes envolvidas. Entre os temas mais conflituosos estão questões básicas, como pagamento dehoras extras, horário para refeições e pagamento de benefícios atrasados.

O s acordos informais ocorrem tanto entre empresas formais e empregados C LT istas como entre empresas informais com trabalhadores informais. N este caso, a estratégia não é a regularização da informalidade durante a vigência do contrato, mas o pagamento dos direitos previstos na CLT ao término do contrato informal. Segundo os entrevistados, essa estratégia evita conflito entre empregados e empregadores, ou a denúncia da falta de registro na carteira de trabalho. A delegada sindical tem atuado no cálculo dos benefícios a que o(a) empregado(a) teria direito se fosse formalizado(a) ou apresentasse queixa à Justiça. Em seu papel de mediadora, muitas vezes ela propõe o parcelamento dos valores devidos. Essa estratégia é utilizada com bastante freqüência e é entendida tanto pela delegada sindical como por empregadores e empregados como uma forma de evitar a demora e a buro-
14. A sede do sindicato dos trabalhadores deste segmento para 0 estado de Goiás localiza-se em Goiânia. 
15. Isso confirma pesquisas realizadas em outras regiões do país, como o estudo levado a cabo em São Carlospor Claro (2003). cracia do sistema judicial. Assim, essa pessoa desempenha ao mesmo tempo papel de representante sindical, mediadora ou conciliadora, promotora informal de Justiça e consultora para empresários em busca de formas de evitar conflitos ou de resolver situações de crise no ambiente de trabalho. Trata-se de uma espécie de líder carismática cuja excepcionalidade que Ihe confere legitimidade é o conhecimento das leis trabal histas - talvez seja o melhor símbolo dessa sociedade em transição do tradicional para o moderno, ou do contrato informal, individual e discricionário para o contrato formal pautado na legislação nacional. Alguns direitos são plenamente (ou quase) respeitados, como 0 salário mínimo e a jornada de 44 horas semanais, incluindo as empresas informais ${ }^{15}$; outros são desrespeitados, sejam normas constitucionais (o trabal ho infantil, por exemplo, presente em acabamentos pós-lavagem em Jaraguá), direitos individuais do trabalho ou normas que dizem respeito ao próprio acesso à Justiça.

0 padrão das relações de trabal ho em Jaraguá, a baixa institucionalidade ou a ausência ou fragilidade das agências do trabal ho (sindicatos, delegacia do trabalho, procuradoria do trabal ho ou consultorias empresariais) são indicadores da baixa consolidação do APL, tal como definimos anteriormente. No caso de Toritama, o grau de institucionalização é ainda mais baixo, seja pela ausência de uma liderança "legal-carismática”, seja pela força do mercado aquecido, que elevou substancialmente os salários dos trabalhadores.

\section{Ruptura como marco de consolidação de APLS}

As histórias de Toritama e Jaraguá reforçam o argumento central deste artigo, ou seja, o do papel fundamental desempenhado por instituições que atuaram como catal isadoras da crise, levando a uma ruptura com o mundo da informalidade e da ilegalidade, e, ao mesmo tempo, contribuíram para a consolidação dos arranjos. Em cada situação, em função dos problemas e especificidades do arranjo, uma instituição foi preponderantena deflagração da crise que levou às mudanças. No caso de Toritama, a informalidade generalizada e a ausência do poder público em serviços básicos de saúde e educação eram vistos como uma questão menor diante do problema da escassez de água na região e da poluição causada pelas lavanderias de jeans. 0 total desrespeito à legislação ambiental foi o responsável pela ação do Estado, particularmente da promotoria pública e do órgão estadual encarregado do meio ambiente, que resultou inicialmente no fechamento das 
lavanderias ena crise em Toritama. 0 sacordos para a solução desse impasse foram possíveis, como veremos adiante, pela atuação conjunta de instituições que atuaram na construção de um sistema de despoluição e aproveitamento da água utilizada para lavar (tingir e amaciar) os jeans.

Antes de se especializar na produção de jeans, Toritama era conhecida no agreste pernambucano, na década de 1950, como município produtor de redes. $N$ as décadas seguintes houve uma tentativa de produzir sapatos de couro, que não conseguiu sobreviver aos calçados sintéticos mais baratos vindos do Sul do país. Segundo informações de empresários locais, a opção de dedicar-se à produção de jeans, no início de 1980, foi influenciada pela proximidade de Santa C ruz do C apibaribe, que já tinha tradição em confecções, e pela experiência passada com fabricação de redes e costura de calçados. D esse momento em diante, a confecção dejeanstornou-sea principal atividade econômica do município, envolvendo, atualmente, cerca de $92 \%$ de sua população ativa em atividades relacionadas à produção de jeans ${ }^{16}$.

A impressão primeira da cidade de Toritama é a de um canteiro de obras onde atividades de produção e lavagem de jeans estendem-se pelo horário noturno e misturam-se à malha urbana, às residências, ao comércio local e aos poucos serviços públicos existentes. Essa impressão é reforçada com a visão do único rio que corta a cidade, em cujas margens estão local izadas as lavanderias do município. A poluição causada pelas atividades das sessenta lavanderias existentes era visível na sua coloração azulescuro, proveniente dos detritos líquidos e sólidos despejados no rio sem nenhum tipo de tratamento.

0 processo de lavagem envolve uma série de produtos químicos altamente poluentes, destinados a mudar a coloração e amaciar o jeans. Estima-sequeas lavanderias deToritama processam 14,4 milhões de jeansanualmente, consumindo 81,8 milhões de litros de água, além de produtos químicos para a descoloração e o amaciamento das peças ${ }^{17}$. Além da poluição causada pelos afluentes lançados ao rio, a população do município estava exposta à fumaça dos fornos que alimentavam as caldeiras das lavanderias eaos riscos de explosões. 0 forteodor emanado eas explosões decal deiras situadas próximas a residências deram origem a uma série de reclamações junto à promotoria local ${ }^{18}$.

As campanhas educativas promovidas pela promotoria pública em conjunto com a prefeitura ecom um empresário-líder no tratamento deafluentes não foram bem-sucedidas. Em agosto 2003, o promotor público, utilizando-se de poderes legais, promoveu junto com agentes estaduais do Contro-
16. Estimativas do Sebrae-PE.

17. U ma descrição detalhada dos efeitos da poluição pode ser encontradanadissertação de mestrado de $\mathrm{M}$ aria Ella Lazarte(2005).

18. $M$ aiores detalhes sobre o papel da promotoria pública e outras instituições públicas no controle da poIuição em Toritama, ver Almeida (2005). 
le do M eio Ambiente Recursos H ídricos (CPRH ) efiscais da secretaria do Trabal ho uma operação de vistoria que resultou no fechamento de dez lavanderias em Toritama num único dia.

Segundo depoimento do promotor público, responsável por deflagrar o processo, o objetivo dessa fiscalização e conseqüente aplicação rigorosa da lei foi convocar empresários do setor a discutir uma solução coletiva para controlar a poluição. A estratégia utilizada pelos agentes públicos foi negociar um acordo (Termo de Referência de Conduta - TAC) em que cada empresário de lavanderia assumia o compromisso de instalar equipamentos para tratamento dos afluentes num período de oito a doze meses, dependendo do tamanho das empresas. Em contrapartida, o poder público, até então ausente do arranjo, comprometeu-se a construir a infra-estrutura de saneamento básico, particularmente a rededeesgoto, para canal izar os afluentes tratados das lavanderias e de outras empresas.

0 cumprimento do acordo foi possibilitado pela atuação conjunta de agentes públicos e privados que contribuíram no sentido de apoiar o desenvolvimento de uma tecnologia de tratamento e reciclagem de água apropriada, como também no de orientar os empresários na busca de financiamento dos equipamentos necessários. Entre as instituições presentes na solução da crise das lavanderias de Toritama destacam-se a promotoria pública local e estadual, a Agência Estadual de M eio Ambiente e Recursos H ídricos, o Instituto de Tecnologia do Estado de Pernambuco, o Sebrae, 0 Sindicato de Confecções e a recém-criada Associação Comercial e Industrial de Toritama. C abe também ressaltar a atuação de uma Associação de D esenvolvimento dos Empresários da Bavária (BFZ), que enviou técnicos

19. Lavanderia M amute, do empresário Edilsom M artins. alemães para desenvolverem, na lavanderia de um empresário líder local ${ }^{19}$, um sistema de tratamento e reciclagem da água com recursos da região e, portanto, a custos inferiores aos sistemas existentes.

Entendemos que a ruptura provocada pelo fechamento das lavanderias poluidoras teve impactos positivos no arranjo porque foi acompanhada da atuação de institui ções que apoiaram e estimularam os empresários na busca de soluções para o problema coletivo da poluição e da escassez de água. Embora persistam na região problemas típicos da informalidade ainda predominante nas confecções, como o não-cumprimento da legislação trabaIhista, a presença de instituições públicas e associações locais abrem novas perspectivas de consolidação do APL de Toritama.

A história de Jaraguá é marcada por uma fase na qual a produção de peças piratas era tão ou mais expressiva que a produção legal. A partir do 
ano 2000, entretanto, as confecções do município passam por um processo de legalização e formalização. Em síntese, podemos dizer que Jaraguá passou por quatro transições: de uma economia predominante rural, passa para a constituição de um pequeno núcleo informal de produtores de confecções para consumo local (1986); depois, com o incentivo de agentes externos ao município, criam-se inúmeras confecções piratas (meados dos anos de 1990); a partir das primeiras denúncias, em 1996, começa uma fase de transição da ilegal idade para a formalização das empresas (2000); agora, vive-se uma fase de formal ização das relações de trabal ho ede construção de instituições de apoio. No período de menos de vinte anos, vários padrões contratuais se seguem e se sobrepõem em Jaraguá: primeiro, a vigência de relações tradicionais e patriarcais típicas de pequenos município de produção predominantemente rural; depois, a criação de empresas informais; em seguida, a adesão de parte delas à produção ilegal; ao mesmo tempo, há também a formalização de empresas e a proliferação de marcas próprias. H oje, empresas formais convivem com um número expressivo de empresas que permanecem informais, todas elas ainda predominantemente familiares e com ambições ao mesmo tempo modernas (trabal hadores qualificados e colaborativos) e patriarcais (visões rígidas de disciplina e hierarquias).

Entre esses processos, o mais marcante para a história de Jaraguá foi o de eliminação (ou reduçãa ${ }^{20}$ ) da produção de marcas piratas. Segundo depoimentos, desde 1996, quando a imprensa divulgou pela primeira vez a produção de jeans falsificados de marcas internacionais, os produtores passaram a receber um número crescente de calotes por parte dos compradores. $N$ a década de 1990, Jaraguá conquistou mercados com uma mescla de produtos de marcas próprias e falsificadas. Alguns produtores locais orgulhavam-se da qualidade da fal sificação e sustentam que, após a interrupção do fluxo de marcas fal sas, seus antigos mercados demandavam a continuidade do comércio com as marcas regulares. D iversas empresas, legais e ilegais, de Jaraguá atuavam em um mesmo mercado. Assim, o APL consolidou três tipos de mercados: aqueles para os quais eram vendidos apenas produtos de marcas próprias; mercados compradores basicamente de produtos fal sificados; e, provavelmente predominantes, mercados compradores de ambos os tipos de confecções.

Enquanto o fluxo de produtos legais era garantido por uma rede derelações familiares e de compadrio, as práticas ilegais eram mantidas mediante relações de confiança pessoal. Além disso, a aceitação por parte do comprador do produto falsificado dava legitimidade à sua produção, banalizava a
20. Esse é por nature za um tema difícil de ser tratado com os entrevistados ou de ser observado por meio de trabalhos de campo. Entretanto, informações de membros do governo do estado de Goiás e de técnicos do Sebrae confirmam nossas evidências de grande redução ou erradicação da produção de confecções piratas. D o ponto de vista desta pesquisa, não éimportante a certeza da erradicação, maso sucesso da transição para marcas próprias por intermédio de empresas formais. 
21. N ão trataremosdas possíveis redes profissionais de promotores da pirataria, o que nos levaria a outro tema. ilegalidadee reduziaa gravidadeda contravenção para os praticantes. A lógica da produção ilegal não é predominantemente enganar o comprador do produto final - embora isso ocorra em escala menor. Além dos evidentes sinais de menor qualidade do produto, o preço informa ao comprador a falsidade da mercadoria. Em produtos da moda, compra-se sabendo ser falso, com o intuito deenganar ou de imitar a classemédia. 0 enganado émenos 0 comprador que aquele que o vêusando o jeans. Como disseram al guns entrevistados, quem vêdelongenunca sabeseum jeansépirata ou não; apenas quem o veste sabe. A aceitação emesmo a demanda são fortes elementos de legitimação da pirataria aosolhos dequem éinduzido a praticá-la ${ }^{21}$.

Junto com a confiança entre os membros da rede da pirataria havia a consciência da impossibilidade de se recorrer a um árbitro externo (a Justiça) em caso de conflitos. D e um lado, as instituições de fiscalização e de justiça eram omissas em Jaraguá. D e outro lado, as instituições de justiça destinadas à resolução de conflitos de contratos privados não poderiam ser acionadas em casos de disputas entre os membros da cadeia de produção ilegal. A Justiça não estava presentee, mesmo que estivesse, não poderia ser acionada pelos agentes privados.

Esse conjunto de lógicas, práticas e naturalização da informalidade poderia ter se perpetuado em Jaraguá. Contudo, quanto mais o mercado se expandiu para fora da região de G oiás, mais frágeis tornaram-se os laços pessoais e os recursos de controle e coerção entre os membros da rede. $A$ distância dos mercados também aumentou o risco de fiscalização das cargas dos caminhões que percorriam longos percursos entre G oiás e o N orte e 0 N ordeste do país. Por fim, a predominância de um sistema de vendas por meio de representantes que faziam a conexão entre Jaraguá e outras regiões do país e a prática de acordos informais de pagamentos parcelados após o recebimento das mercadorias aumentaram os riscos dos produtores ilegais. Q uanto mais o mercado de Jaraguá se expandia, mais agentes externos ao município (especialmenterepresentantes) entravam na rede, tornando cada vez mais frágeis os laços de confiança e controle. Esse processo de dissolução da rede de produção, venda e transporte de mercadorias piratas culminou no ano 2000, quando um calote generalizado levou à falência os principais produtores ilegais.

A concentração de calotes nos anos de 2000 foi a culminação do processo simultâneo de expansão do mercado de Jaraguá e de perda de controle da rede municipal. Embora as visitas da fiscalização e da polícia federal ao município possam ter tido al gum papel de coibir a produção pirata, a lega- 
lização da produção foi induzida principalmente pelos constrangimentos que o mercado nacional formal impôs ao município. Compradoresformais demandando notas fiscais e a fiscalização rodoviária exigiam a presença de empresas formais patrocinando o mercado ilegal. 0 sucesso dessas empresas tornava os investimentos crescentes e criava contratos informais mais sofisticados com sistemas de pagamentos parcelados. 0 "pacto com o diabo"22, bem descrito por Tendler (2003) em sua análise sobre a tolerância e até mesmo 0 incentivo da política municipal para arranjos informais em Pernambuco, teve vida curta em Jaraguá devido à sua integração com 0 mercado nacional formal.

A pós o ano 2000, os produtores de Jaraguá foram capazes de se reestruturar por causa de um conjunto de fatores: a difusão de habilidades específicas construídas ao longo da década de 1980; a ampliação da capacidade instalada das empresas ocorrida ao longo da década seguinte, e que então se tornaram ociosas; a consolidação de mercados para os jeans de marcas de Jaraguá; a consolidação das relações com a indústria têxtil paulista, que ampliou as possi bilidades de crédi to para a retomada da produção. No caso de Jaraguá, a produção ilegal contraditoriamente induziu as empresas à legal ização e à formalização. $M$ as esse não é um caminho natural. 0 sucesso da transição de Jaraguá decorre tanto dessa forma particular de o APL integrar-se ao mercado nacional, como da consolidação paralela de um mercado para as marcas de Jaraguáe, por fim, do engajamento detrêsinstituições no apoio à reestruturação do arranjo: Associação Industrial Comercial de Jaraguá, Sebrae e Senai.

Sintomático da nova situação é o papel que essas três instituiç̧ões vêm desempenhando desde2000 na promoção deatividades no arranjo. A Associação Industrial Comercial de Jaraguá (AICJ), embora fundada em 1984, somenteno início da década passou a ser vista como interlocutor dosinteresses dos empresários da confecção. Praticamente todos os empreendedores entrevistados iniciaram suas atividades sem buscar apoio denenhuma instituição. Entretanto, hoje, a maioria dos empresários com empresas formais tem contato freqüente com a associação, tanto para buscar informações e apoio para a realização ou ida a feiras demoda, como para buscar treinamento próprio ou para seus empregados. Já o Sebrae-GO é percebido pelos entrevistados como uma instituição capaz de atender as necessidades de qualificação eorientação para promoção deum ambienteempresarial profissional. O Senai, por sua vez, até o momento aúnica instituição em Jaraguá orientada para a qual ificação dos trabal hadores de confecções, vem desde 2000 pro-
22. A autora defineesse devil's deal como "um acordo não explícito entre políticos e a miríade de proprietários de pequenas empresas, a maioria do setor informal. Com esse acordo, 'se você vota em mim não irei coletar os impostos devidosenão farei vocêarcar com outros impostos, leis trabalhistas e legislação ambiental. Ademais, vou manter a fiscalização (polícia e inspetores) afastada'. [...] U ma vez queesse pacto éfeito, torna-se difícil para qualquer uma das partes sair desse acordo [...]" (Tendler, 2003, p. $3)$. 
23. O stermosmaisfreqüentes utilizados para definir esseconjunto de atitudes e comportamentosforam: "vestir a camisada empresapara comprometimento" e "saber operar váriasmá quinas efazer seu serviço sem erro".

24. A esse respeito, ver N oronha (2003). movendo cursos de costureiros(as) industriais. A dificuldade de encontrar mão-de-obra qualificadaéum dos problemas mencionadosem todos os segmentos do processo produtivo.

O s empresários, ao mencionarem o tema da qualificação dos funcionários, estavam se referindo, além dos conhecimentos de técnicas e práticas típicas de confecção, a um conjunto de atitudes e comportamentos típicos ou esperados em formas modernas de organização da produção, tais como interesse na qualidade do seu produto, flexibilidade, envolvimento, comprometimento ${ }^{23}$. A expectativa de tais atitudes e comportamentos não parece ter contrapartida nos planos de qualificação da empresa. Tanto a delegada sindical como os professores da rede pública de ensino entrevistados apontaram a dificuldade dos al unos que trabal ham deconcluir cursos, mesmo que noturnos, dadas as exigências dehoras extras e a impossibilidade de os empregados deixarem o trabal ho mais cedo (ainda que apenas quinze minutos) para chegar à escola. Essa é uma condição ainda mais complexa que aquela apontada por Guimarães (2004, pp. 351-365), ao destacar a precariedade dos welfare públicos e privados no Brasil moderno. Trata-se de uma situação na qual os contratos de trabalho informais dinamitam a eficácia potencial dos serviços públicos ali oferecidos.

Esse é o retrato de um Arranjo Produtivo Local, semelhante a muitos outros existentes em municípios do interior do país, onde formas modernas e arcaicas, o precário, o ilegal, o informal e o formal, as noções de justo e de injusto ${ }^{24}$ aparecem mesclados e refletidos em praticamente todos os estágios do processo produtivo e nos padrões de relações institucionais.

Diversidade de instituições relevantes na análise do desenvolvimento de arranjos produtivos

0 debate sobre política industrial no Brasil passa por renovações ainda tímidas eincertas, mas aponta para a val orização do desenvolvimento declus ters ou APLs, supondo que possam ter efeitos positivos no aumento da produção, na qualidade do produtos, no seu valor agregado, na exportação eno desenvolvimento do mercado interno. A promoção deAPLsdemão-de-obra intensiva coloca necessariamenteem debateos víncul os entrepolítica industrial e política de emprego. $\mathrm{N}$ a cultura predominante dos formuladores de políticasindustriais, estasnão podem ser subordinadasa metas explicitamentesociais, incluindo o emprego como tal. D a mesma maneira, para osformuladores de políticas de emprego, estas não devem ser subordinadas às políti- 
casindustriaisou setoriais. Entretanto, quando sediscutea evolução deAPLs demão-de-obra intensiva ebaixa tecnologia, osvínculosentreas duas políticas são inevitáveis, independentemente das culturas de seus formuladorese das vocações dos ministérios e órgãos governamentais que as promovem.

O significado social do sucesso ou do fracasso de APLs, como os de Jaraguá ou de Toritama, supera em muito seus eventuais impactos na balança comercial ou em termos de desenvolvimento tecnológico. APLs demão-deobra intensiva em geral estão associados à informalidade (quando não à manufatura de produtos piratas) das empresas e do trabal ho, ao trabal ho infantil, à evasão escolar e ao desrespeito a princípios de saúde e de segurança do trabalho. M uitos deles também sesituam em municípios nos quaisa produção especializada do arranjo produtivo é a principal geradora de emprego e renda em sua região urbana. D estarte, a despeito da inspiração italiana que explica o entusiasmo demuitosanalistas eformuladores depolíticas deapoio a pequenas empresas, no caso brasileiro os el ementos de inovação e de geração derenda são possi velmente secundários(embora relevantes) em relação à complexidade das mudanças detradições, val ores, práticas e padrões contratuais pelasquaistaisAPLs passam paraseconsolidarem como algo legítimo e até mesmo para serem objeto de políticas propriamente industriais. Antecederam-nas as políticas deerradicação de práticasilegais(Jaraguá), a preservação do bem mais escasso e essencial para a produção de jeans (a água, em Toritama) eo início da formalização dos contratos, em ambos os casos.

Supomos que a ampliação de estudos sobreAPL sque passaram por transições positivas venha a mostrar que os momentos de ruptura estiveram ligados ao equacionamento dos elementos mais deletérios para a comunidade local e vinculados a contextos que deixam os produtores numa situação limite na qual seus benefícios privados comprometem bens públicos que afetam atores externos ao APL. O s dois casos estudados representam histórias de APLs intensivos em mão-de-obra que se consolidaram de forma exógena, isto é, tanto pelo reconhecimento dos mercados compradores evendedores como pela ação de agentes externos aos APL s com a finalidade de romper práticas nocivas.

Avaliações de mel horia de qualidade de vida (e de emprego) são bastante complexas. Jaraguá é certamente um caso bem-sucedido do ponto de vista da geração de empregos. M as a informalidade, os baixos salários, o trabal ho intensivo, as rígidas hierarquias ea presença do trabal ho infantil são indicadores evidentes de precariedade nas relações de trabal ho. É possível que, apesar disso, tais condições sejam superiores àquela existente antes do de 
senvolvimento da indústria de confecções no local. M as, do ponto de vista das políticas públicas, tal precariedadeindica serem essas as áreas de atuação prioritárias, sem as quais o arranjo produtivo perde sua importância primordial de desenvolvimento social local. Já em Toritama há evidências claras do descompasso entre o crescimento da renda dos trabalhadores e a precariedade dos serviços públicos essenciais. Trata-se de um caso clássico de pacto diabólico (Tendler, 2002), no qual a população e os empresários não pagam impostos e os governantes não oferecem serviços públicos.

Argumentamos neste artigo que a análise do ambiente institucional no qual um APL está inserido explica a forma eas razões de sua eventual consolidação. A história de Jaraguá foi marcada por uma ruptura no ano 2000, causada pela sua expansão para o mercado externo. Práticas e padrões contratuais locais foram alterados quanto mais se intensificaram os vínculos com mercados nacionais estruturados. 0 mercado formal nacional éa instituição mais relevante para explicar as mudanças dos padrões produtivos e contratuais de araguá. A téaqueleano, instituições locais, associações, sindicatos, agências paragovernamentais e prefeituras foram irrelevantes no seu desenvolvimento. $\mathrm{N}$ a reestruturação das empresas, os agentes internos começam a agir. $M$ as a capacidade desuperação da crise deve-se principalmenteao aproveitamento doslaçosformais demercado quehaviam sido consolidados pelos empresários nos anos anteriores, de forma paral ela aos vínculos informais. $\mathrm{H}$ oje Jaraguá encontra-se em processo de possível consolidação endógena, decriação de instituições locais que Ihe dêem solidez para enfrentar crises para além dos recursos individuais de cada empreendedor.

No caso de Toritama, foi a ação deliberada edecisiva de agentes públicos locais (particularmente o M inistério Público), associados a diversos outros órgãos públicos (fiscais de renda, do trabal ho, secretarias estaduais de Pernambuco), que induziu a ruptura da prática de poluição dos rios que comprometia 0 acesso à água de toda a população do agreste pernambucano ea própria produção local dejeans. A ação intimidadora do M inistério Público foi compensada posteriormente por instrumentos de ajustamento de conduta, o que poderá conduzir a uma melhoria considerável do descompasso entre a renda (comparativamente alta) dos trabalhadores de Toritama e a pobreza dos equipamentos urbanos do município.

A história, os problemas, os agentes relevantes, as organizações presentes nos APL s de Jaraguá e de Toritama diferem em muito daqueles apontados em estudos sobre clustersantigos e consolidados. Como símbolo de um tipo de política, a polissemia do termo "APL" tem muitas razões de ser. 
$M$ as, como conceito acadêmico, seus limites devem ser mais estreitos. A partir de análises realizadas em diversos estudos sobre desenvolvimentos de clusters, cadeias produtivas ou APLs, vêse que as instituições relevantes que explicam o surgimento, o desenvolvimento e, portanto, a lógica das práticas de cooperação e conflito variam consideravelmente.

Por exemplo, a análise do caso do desenvolvimento daindústria cal çadista no C eará na década de 1990 constatou a importância decisiva da ação do governo estadual em termos de incentivos fiscais e promoção de cooperativas de legalidade discutível (cf. Lima, 2000). Explicar o caso do Ceará com base na dinâmica da interação entre mercados local e externo à região pode ser útil, assim como o papel decisivo da promotoria pública em Toritama. $M$ as, antesdisso, estão as escolhas governamentais. Trata-sedeum desenvolvimento explicitamente induzido pela ação governamental, subordinando lógicas de mercado e até mesmo tipos de contratos entre empregados e empregadores. A "instituição" relevantequeo estrutura (a política industrial do governo estadual) difere em muito das práticas tradicionalistas, familiares, informais e de múltiplos atores que geraram os pólos de Jaraguá eToritama. D iferetambém dehistórias de muitos outros clustersantigos, com organizações locais consolidadas ebem estruturadasorganizacional efinanceiramente se comparadas à inexistência ou à fragilidade das organizações locais de Jaraguá. No Vale dos Sinos, os interesses diferenciados de pequenos e grandesempresários, a dinâmica das associações empresariais, as históriasdeconflito entre os segmentos de couro e o de calçados, a tradição corporativa de seus sindicatos, com forte cultura setorial, definem e reforçam continuamente padrões antigos de cooperação e de conflito (cf. N oronha eTurchi, 2002). U ma análise do grau de consolidação endógena e exógena de tais clusters ou APLs não apenas mostra níveis e padrões bastante diferenciados deconsolidação como também aponta a existência degrande diversi dade de ambientes institucionais, e seus componentes (tais como normas predominantes e organizações relevantes) são ainda pouco explorados.

Referências Bibliográficas

Almeida, M . (2005), Understanding incentives for clustered firms in Brazil to control for pollution: the case of Toritama. Brasília, I pea, abril, p. 54.

Cassiolato, J. E. \& Lastres, H. M. M. (2003), "O foco em arranjos produtivos e inovativos locais de micro e pequenas empresas". In: LASTRES, H. M. M. et al. 
(eds.). Pequena empresa: cooperação e desenvolvimento local. R io de Janeiro, Relume D umará.

Claro, C . D . (2003), Contratosinformais em pequenas empresas na cidade de São Carlos. São C arlos, dissertação de mestrado, D epartamento de C iências Sociais, U fscar.

DI Maggio, P. \& Powell, W. W. (1983), “The Iron cage revisited: institutional isomorphism and collective rationality in organizational fields". American Sociological Review, 48 (2): 147-160.

Gereffi, G. \& Korzeniewicz, M . (1990), "Commodity chains and footwear in the semiperiphery". In: M ARTIN, W. G. (ed.). Semi peripheral statesin the world-economy. N ova York, Greenwood Press, Commodity chains and footwear in the semiperiphery, pp. 45-68.

Gran ovetter, M. \& Swedberg, R. (eds.). (1992), The sociology of economic life. San Francisco, Westview Press.

Grun, R. (1992). N egócios e famílias: armênios em São Paulo. São Paulo, Sumaré, Série Imigração, vol. 3.

Guim ARÃEs, N . A. (2004), Caminhos cruzados: estratégi as de empresas e trajetórias de trabalhadores. São Paulo, Editora 34.

H ollingsworth , J. R. (2003), "Advancing the socio-economic paradigm with institutional analysis". Socio-economic Review, 1 (1): 130-134, jan.

LAZARTE, M . E. J. (2005), Successful public sector enforcement of environmental standards in the Toritama Jeans Industry in Pernambuco, Brazil. Departament of Urban Studies and Planning, M assachusetts Institute of Technology.

LımA, J. C. (2000), "A subcontratação em cooperativas de trabalho no N ordeste: descentralização produtiva e flexibilização das relações de trabalho". In: ABREU, A. R. D. P. (ed.). Produção flexível e novas institucionalidades na América Latina. Rio de Janeiro, Editora da UFRJ, pp. 255-269.

Locke, R. M . (2004), Building Trust. M assachusetts Institute of Technology - M IT. Lopes, J. R. B. (1967), Crise do Brasil arcaico. São Paulo, D ifel (col. Corpo e Alma do Brasil).

M ARSDEN, D. (1986), The end of economic man? Custom and competition in labour market. N ova York, St. M artin's Press.

N oronha, E. G. (2003), "Informal, ilegal, injusto: percepções do mercado de trabaIho no Brasil". Revista Brasileira de Ciências Sociais, 18 (53): 111-129.

N oronha, E. G. \& T URCHI, L. M . (2002), "Cooperação e conflito: estudo de caso do complexo coureiro-calçadista no Brasil". TD-IPEA - Texto para D iscussão, n. 861, março, pp. 5-42.

O Lson, M . (1999), A lógica da ação coletiva: os benefícios públicos e uma teoria dos grupos sociais. 1ạ edição 1955. São Paulo, Edusp (col. Clássicos, 16). 
Putnam, R. (1993), M aking democracy work. Princeton, Princeton University Press.

Reynaud, B. (2004), Les règles économiques et leurs usages. Paris, O dile Jacob (col. Économie).

So Low, R. M . (1990), Thelabor market asa social institution. O xford, Basil Blackwell. Suzigan, W., Furtado, J. et al. (2003). "Sistemas locais de produção: mapeamento, tipologia e sugestões de políticas". Trabalho apresentado no XXXI Encontro N acional de Economia. Porto Seguro, BA, 9-12 dez.

Swedberg, R. (1994), "M arkets as social structures”. In: Smelser, N . \& Swedberg, R. (eds.). The handbook of economic sociology. Princeton, Princeton University Press, M arkets as social structures, pp. 255-282.

Tendler, J. (2002), "Small firms, the informal sector, and the devil's deal". IDS Bulletin, 33 (3). . (2003), "Pequenas empresas, o setor informal e o 'pacto com o diabo'". Política e Trabalho - Revista de Ciências Sociais, 19, set.

UFRJ, Instituto de Economia. (2003), 0 foco em arranjos produtivos e inovativos locais de micro e pequenas empresas, pp. 21-34.

\section{Resumo}

O pulo do gato da pequena indústria precária

0 artigo apresenta os resultados de pesquisa sobre o processo de transição da ilegalidade e/ou informalidade para a formalidade, vivenciado por arranjos produtivos intensivos em mão-de-obra e inseridos em mercados precários nas regiões $\mathrm{N}$ ordeste e Centro-oeste do Brasil. A pesquisa revelou que o processo de mudança resultou de momentos de crise ou rupturas, e não de uma evolução em que os atores teriam sentido necessidade de cooperar para a solução de problemas de interesse coletivo. Essa cooperação foi posterior ou, mais especificamente, só foi possível pela atuação de instituições que deram origem à crise e estiveram presentes em seu enfrentamento. Em Jaraguá (GO), a instituição determinante da mudança foi o aparato legal necessário para a inserção no mercado formal; em Toritama (PE), a promotoria pública e a agência governamental de meio ambiente levaram à necessidade de buscar soluções menos poluentes entre os empresários locais.

Palavras-chave: Instituições; Arranjos produtivos locais; Política industrial.

\section{Abstract}

Tricks up their sleeves: business strategies in small industries

This paper presents the main research findings of a study conducted in two industrial districts and what I refer to here as Local Industrial Arrangements - LIAs. The research focuses on the transition from a situation characterized by informal or illegal 
production, low wages and precarious work conditions, to one characterized by high levels of productivity/quality/fair labour conditions. The findings of the empirical study reveal the importance of specific institutions in the transition from a widespread informality to the more stable and sustainable situation of the LIAs. In the case of Jaraguá (GO ), it was the legal framework that enabled this change and the subsequent impact on local development, while in the case of Toritama (PE), transition was stimulated by the cooperation between legal and environmental institutions. Keywords: Institutions; Clusters; Industrial policy.

Texto recebido em $1 /$ $7 / 2004$ eaprovado em $1 / 7 / 2004$.

Eduardo Noronha é professor do D epartamento de Ciências Socais da Universidade Federal de São Carlos - U fscar. Email: enoronha@uol. com.br.

LenitaTurchi épesquisadora do Instituto de Pesquisa Econômica Aplicada - I pea. Email: turchi@ipea.gov. br. 